\title{
A Protocol for Rapid and High-Frequency In Vitro Propagation of Solanum nigrum L.
}

(Protokol bagi Pembiakan Pantas dan Berfrekuensi Tinggi In Vitro Solanum nigrum L.)

\author{
LI-JUAN ZOU, JING-TIAN YANG \& QING-GUI WU*
}

\begin{abstract}
Solanum nigrum $L$. is a species highly valued for its medicinal properties. In the present study, an efficient propagation system was established by using five explants of $\mathrm{S}$. nigrum namely, roots, leaves, rooted hypocotyls, nodal segments and petioles. Various types of plant growth regulators (PGRS) were used to determine the most effective hormone combination for callus induction and organogenesis. Zeatin (ZT), thidiazuron (TDZ), kinetin (Kin) and indole-3-acetic acid (IAA) were found to induce multiple shoots. Shoot organogenesis was induced in the five explants. The highest mean for number of shoots per petioles (31.54 \pm 5.76$)$ and rooted hypocotyls $(44.00 \pm 1.51)$ with a $100 \%$ induction rate was obtained on Murashige and Skoog (MS) medium fortified with $0.4 \mathrm{mg} / \mathrm{L}$ IAA and $3.0 \mathrm{mg} / \mathrm{L} \mathrm{ZT.} \mathrm{MS} \mathrm{medium} \mathrm{containing} 0.4 \mathrm{mg} / \mathrm{L}$ IAA and $3.0 \mathrm{mg} / \mathrm{L} \mathrm{TDZ}$ was found to be optimal for shoot regeneration of roots, leaves and nodal segments. The highest regeneration frequency (100\%) with mean numbers of shoots equal to $38.77 \pm 6.87$ for roots, $42.73 \pm 7.75$ for leaves and $56.73 \pm 7.98$ for nodal segments was produced. Regenerated shoots rooted effectively on half-strength MS medium and acclimatized successfully in soil with a $100 \%$ survival rate and normal growth. The protocol can be used for the largescale propagation of $\mathrm{S}$. nigrum to meet the increasing demand of commercial cultivation.
\end{abstract}

Keywords: Callus; explants; in vitro propagation; organogenesis; Solanum nigrum

\section{ABSTRAK}

Solanum nigrum L. adalah satu spesies yang amat dihargai bagi sifat perubatannya. Dalam kajian ini, sistem pembiakan cekap telah ditubuhkan dengan menggunakan lima eksplan daripada S. nigrum iaitu akar, daun, hipokotil berakar, nod segmen dan petiol. Pelbagai jenis pengatur pertumbuhan tumbuhan (PGRs) telah digunakan untuk menentukan gabungan hormon paling berkesan untuk aruhan kalus dan organogenesis. Zeatin (ZT), thidiazuron (TDZ) kinetin (Kin) dan asid indol-3-asetik (IAA) dilihat berjaya mengaruh beberapa pucuk. Pucuk organogenesis telah diaruh dalam lima eksplan.

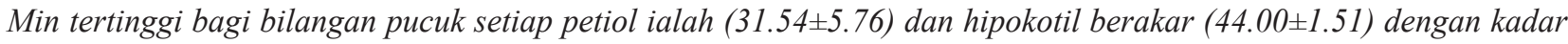
aruhan 100\% diperoleh pada medium Murashige dan Skoog (MS) dengan 0.4 mg/L IAA dan $3.0 \mathrm{mg} / \mathrm{L} \mathrm{ZT.} \mathrm{Medium} \mathrm{MS}$ mengandungi $0.4 \mathrm{mg} / \mathrm{L}$ IAA dan $3.0 \mathrm{mg} / \mathrm{L}$ TDZ dilihat optimal untuk pertumbuhan semula pucuk untuk akar, daun dan nod segmen. Kekerapan penjanaan semula tertinggi (100\%) dengan purata bilangan pucuk sama dengan $38.77 \pm 6.87$ untuk akar, $42.73 \pm 7.75$ daun dan 56.73 \pm 7.98 untuk nod segmen telah dihasilkan. Penghasilan semula pucuk berakar berkesan pada medium MS setengah-kekuatan dan berjaya mengaklimatisasikan dalam tanah dengan kadar kemandirian 100\% dan pertumbuhan yang normal. Protokol ini boleh digunakan untuk pembiakan S. nigrum secara besar-besaran untuk memenuhi permintaan yang semakin meningkat dalam penanaman secara komersial.

Kata kunci: Eksplan; kalus; organogenesis; penanaman secara in vitro; Solanum nigrum

\section{INTRODUCTION}

Solanum nigrum L. is perennial plant, commonly known as 'black nightshade'. It has been widely used in traditional medicine for its possesses of many antioxidant properties due to its abundant secondary metabolites, such as phenolics (gallic acid, caffeic acid, gallocatechin and quercetin), alkaloids, steroid alkaloids, steroidal saponins, carotenoids and glycoproteins (Ben et al. 2016; Jain et al. 2011; Wang et al. 2011). S. nigrum has been extensively used to treat various ailments such as pain, inflammation (Acharya \& Pokhrel 2006; Zakaria et al. 2006), liver disorders (Lin et al. 2008), diarrhea and eye diseases and cancer (Jain et al. 2011; Tai et al. 2013). Due to its potent anticancer properties, recent studies have focused on its medicinal components, especially its phytochemical constituents (Ewais et al. 2015), antimicrobial activities (Khan et al. 2015) and anticancer mechanisms (Jawad et al. 2015). In addition to its economic importance as a medicinal plant, S. nigrum was characterized as a newly discovered hyperaccumulator of cadmium (Cd) (Jiang et al. 2016; Khan et al. 2014) and the mechanisms of $\mathrm{Cd}$ accumulation have attracted increasing attention (Soares et al. 2016; UdDin et al.2015). The plant is not cultivated, nevertheless, it is extensively harvested from the wild, leading to the possibility of its becoming an endangered species in the near future. However, to fulfill the demand 
of the pharmaceutical industry and to provide a continuous supply of the plant throughout the year, there is an urgent need to adopt some new cultivation approaches.

In vitro culture of plant tissues has been used as a useful approach for the mass propagation and conservation of some rare and endangered species, especially those with high medical value. In vitro clonal propagation of $S$. nigrum was reported previously. Studies on somatic embryogenesis (Xu et al. 2014), the regeneration of rooted hypocotyls and leaves (Xu et al. 2009) and liquid culture for micropropagation of nodal explants (Sarethy et al. 2014), have been conducted. However, to date a complete set of high-frequency regeneration systems (various explants-regeneration-rooting-transplant-survival) has not been established. In the present study, rapid and reliable protocol for multiple shoot induction and propagation of various explants (petioles, rooted hypocotyls, roots, leave and nodal segments) of $S$. nigrum was established. Shoot induction and mean shoot number from various explants exhibited different responses. Interestingly, nodal segment explant induction of shoot regeneration was achieved in two different ways: indirect organogenesis (from the basal knot of the nodal segment) and direct organogenesis (clumps from the axillary bud), and these results have not been reported to our knowledge. The shoots obtained were rooted, and the plantlets obtained were acclimatized.

\section{MATERIALS AND METHODS}

\section{PLANT MATERIAL AND CULTURE CONDITIONS}

Plants of $S$. nigrum with mature fruits were obtained from Mianyang Forest Park, China. The botanical identity the species was authenticated by Professor Ming-hua Luo, Mianyang Normal University. Berries of S. nigrum were surface-sterilized in $75 \%(\mathrm{v} / \mathrm{v})$ ethanol for $30 \mathrm{~s}$, soaked in $0.1 \%(\mathrm{w} / \mathrm{v}) \mathrm{HgCl}_{2}$ solution for 4-6 min and rinsed five times with sterilized distilled water. For germination, the sterilized fruits were cut and seeds were exposed to Murashige and Skoog (MS) (1962) medium supplemented with $1.0 \mathrm{mg} / \mathrm{L}$ gibberellic acid $\left(\mathrm{GA}_{3}\right)$. Hormone-free MS medium was used as a control. MS media was prepared with $2 \%(\mathrm{w} / \mathrm{v})$ sucrose and $0.7 \%(\mathrm{w} / \mathrm{v})$ agar. The $\mathrm{pH}$ of the medium was adjusted to $\mathrm{pH} 5.8$ and the medium was then autoclaved at $121^{\circ} \mathrm{C}$ for $20 \mathrm{~min}$. Cultures were maintained at $24 \pm 1^{\circ} \mathrm{C}$ under a $16 / 8 \mathrm{~h}$ light/dark cycles of medium light $\left(100 \mu \mathrm{mol} \mathrm{m} \mathrm{m}^{-2} \mathrm{~s}^{-1}\right)$. Seedlings were allowed to grow $3-5 \mathrm{~cm}$ prior to for the next step. MS basal medium was used for all stages of micropropagation.

\section{MULTIPLE SHOOT INDUCTION}

To test the effects of phytohormones on the regeneration, petioles, rooted hypocotyls, roots, leaves and nodal segments were carefully excised from the aseptic seedling following 2 weeks of culture and they were used in several subsequent shoot assays. Assays were variously supplemented with growth regulators appropriate for the stage. To study the effects of different hormone combinations on shoot production by various explants, the cultures were initiated on MS medium supplemented with various concentrations of indole-3-acetic acid (IAA), 6-benzylaminopurine (BAP), kinetin (Kin), thidiazuron (TDZ), zeatin (ZT) and a-naphthaleneacetic acid (NAA). Thirty explants were tested for each treatment and each experiment was replicated three times. Shoot regeneration and the number of shoots per explant were recorded after 4 weeks.

\section{ROOT DEVELOPMENT AND ACCLIMATIZATION}

Adventitious shoot clumps were divided into single or very few shoots that were transferred equally to different $1 / 2 \mathrm{MS}$ media combinations containing NAA or no PGRs to induce roots. Root formation was investigated after 30 days of culture. Thereafter, rooted plantlets were removed from in vitro culture, rinsed in distilled water to eliminate debris, transferred to plastic pots containing peat and vermiculite $(3: 1 \mathrm{v} / \mathrm{v})$ and covered with transparent plastic. The plants were maintained under high humidity for 4 weeks and slowly weaned to lower humidity. All surviving plants were transferred to a net house after 6 weeks.

\section{STATISTICAL ANALYSIS}

All treatments were repeated three times with each treatment containing 60 explants per experiment. All treatments were prepared in duplication ( $n=60$ for explants or $n=50$ for root explants). The data (number of shoots induced) were compared by analysis of variance (oneway ANOVA). Duncan's multiple range test was applied at 0.05 level of probability to compare individuals within a treatment (Gomez \& Gomez 1984) using SPSS 18 software.

\section{RESULTS}

\section{SHOOT REGENERATION FROM PETIOLE AND ROOTED HYPOCOTYLS EXPLANTS}

In comparison to control where the germination rate hardly reached 3\% (Figure 1(A)), seeds were fully germinated after 2 weeks on MS medium supplemented with $1.0 \mathrm{mg} / \mathrm{L} \mathrm{GA}_{3}$ (Figure 1(A1); data not shown). Three-week-old seedlings germinating in vitro were used as the source of explants. Petioles $( \pm 1 \mathrm{~cm})$ and rooted hypocotyls $( \pm 1 \mathrm{~cm})$ were isolated and cultured in MS culture media containing various concentrations of PGR. Petioles were placed parallel to the surface of the media and rooted hypocotyls were inserted vertically into the media. Two explants cultured on different media showed different responses (Table 1). Organogenesis from petioles and rooted hypocotyls was induced indirectly via an intervening callus phase. Initially, petioles explants became swollen. After 7 days, both ends of the explants were covered with compact and pea- green callus, which exhibited a dumbbell mode (Figure 1(B)). Rooted 


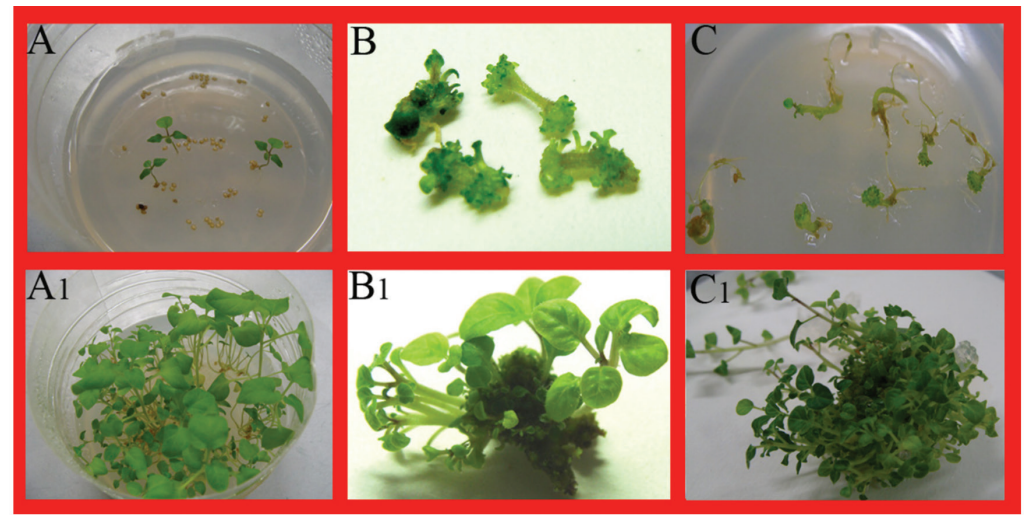

FIGURE 1. Seed germination and in vitro propagation of S. nigrum. A and A1, seedlings germinated after two weeks; B and B1, petiole explants cultured on MS media with $0.4 \mathrm{mg} / \mathrm{L}$ IAA and $3.0 \mathrm{mg} / \mathrm{L} \mathrm{ZT}$; C and $\mathrm{C} 1$, rooted hypocotyls explants cultured on MS media with $0.4 \mathrm{mg} / \mathrm{L} \mathrm{IAA}$ and $3.0 \mathrm{mg} / \mathrm{L} \mathrm{ZT}$

TABLE 1. Effect of various concentration of PGR on callus induction and shoots regeneration of S. nigrum

\begin{tabular}{ccccccc}
\hline PGRs (mg/L) & & \multicolumn{3}{c}{ Petioles } & \multicolumn{2}{c}{ Rooted hypocotyls } \\
\hline IAA & KT & Zeatin & $\begin{array}{c}\text { Callus induction } \\
\text { percentage }\end{array}$ & $\begin{array}{c}\text { Mean shoot } \\
\text { number }\end{array}$ & $\begin{array}{c}\text { Callus induction } \\
\text { percentage }\end{array}$ & $\begin{array}{c}\text { Mean shoot } \\
\text { number }\end{array}$ \\
\hline 0 & 0 & 0 & $0 \mathrm{~h}$ & $0 \pm 0 \mathrm{e}$ & $0 \mathrm{f}$ & $0 \mathrm{~d}$ \\
0 & 1.0 & 0 & $45.2 \mathrm{~g}$ & $6.21 \pm 1.23 \mathrm{~cd}$ & $53.0 \mathrm{e}$ & $4.00 \pm 1.21 \mathrm{~d}$ \\
0 & 3.0 & 0 & $49.5 \mathrm{f}$ & $7.32 \pm 2.73 \mathrm{~cd}$ & $65.9 \mathrm{de}$ & $7.57 \pm 4.62 \mathrm{c}$ \\
0 & 0 & 1.0 & $60.0 \mathrm{e}$ & $12.08 \pm 4.96 \mathrm{bc}$ & $69.3 \mathrm{~d}$ & $11.76 \pm 3.72 \mathrm{bc}$ \\
0 & 0 & 3.0 & $67.1 \mathrm{de}$ & $15.79 \pm 6.21 \mathrm{bc}$ & $82.5 \mathrm{bc}$ & $14.26 \pm 3.58 \mathrm{~b}$ \\
0 & 0 & 4.0 & $79.7 \mathrm{bc}$ & $14.31 \pm 4.84 \mathrm{bc}$ & $73.8 \mathrm{~d}$ & $13.79 \pm 2.97 \mathrm{bc}$ \\
0.4 & 1.0 & & $71.9 \mathrm{bcd}$ & $12.56 \pm 2.12 \mathrm{bc}$ & $87.4 \mathrm{bc}$ & $12.59 \pm 5.80 \mathrm{bc}$ \\
0.4 & 2.0 & & $73.9 \mathrm{bcd}$ & $17.84 \pm 4.8 \mathrm{bc}$ & $92.5 \mathrm{ab}$ & $17.34 \pm 6.19 \mathrm{~b}$ \\
0.4 & 3.0 & & $80.5 \mathrm{bc}$ & $19.37 \pm 4.58 \mathrm{~b}$ & $83.4 \mathrm{bc}$ & $19.17 \pm 4.37 \mathrm{ab}$ \\
0.4 & 4.0 & & $71.0 \mathrm{bcd}$ & $14.85 \pm 3.82 \mathrm{bc}$ & $79.4 \mathrm{c}$ & $16.50 \pm 5.95 \mathrm{~b}$ \\
0.4 & & 1.0 & $80.2 \mathrm{bc}$ & $14.21 \pm 5.10 \mathrm{bc}$ & $88.2 \mathrm{~b}$ & $16.63 \pm 6.97 \mathrm{~b}$ \\
0.4 & & 2.0 & $88.4 \mathrm{~b}$ & $22.90 \pm 2.17 \mathrm{ab}$ & $95.9 \mathrm{ab}$ & $22.85 \pm 7.25 \mathrm{~b}$ \\
0.4 & & 3.0 & $100.0 \mathrm{a}$ & $31.54 \pm 5.76 \mathrm{a}$ & $100.0 \mathrm{a}$ & $44.00 \pm 1.51 \mathrm{a}$ \\
0.4 & & 4.0 & $92.8 \mathrm{ab}$ & $26.18 \pm 3.48 \mathrm{ab}$ & $91.1 \mathrm{ab}$ & $18.66 \pm 3.96 \mathrm{~b}$ \\
\hline
\end{tabular}

Means followed by different letter in a column are statistically significant at $p<0.05$

hypocotyl segments showed a morphogenic response. The development process of regenerated shoots was recorded after 2 weeks of culture. Callus and shoots were all induced by explants on medium containing Kin or ZT alone. No response was observed in control media compared to treated media. The combination of IAA and ZT promoted a significant increase in callus and shoot formation relative to that induced by the combination of IAA and Kin. MS supplemented with $0.4 \mathrm{mg} / \mathrm{L}$ IAA and $3.0 \mathrm{mg} / \mathrm{L} \mathrm{ZT}$ was the most effective combination for petioles and rooted hypocotyls in all the treatments, with $31.54 \pm 5.76$ and $44.00 \pm 1.51$ shoots produced per explant, respectively. Evidence of a low percentage of hyperhydricity was observed with these treatments.

\section{SHOOT REGENERATION FROM IN VITRO-DERIVED ROOT, LEAF AND NODAL SEGMENT EXPLANTS}

The roots, leaf and nodal segment explants were inoculated in different concentrations and combinations of IAA, Kin, ZT and TDZ in MS media (Table 2). Roots were placed parallel to the surface of the media, leaf explants were placed with the abaxial side downwards and nodal segment explants were inserted vertically into the media. The explants failed to develop adventitious shoots in a hormone-free medium even after 35 days of culture (Table 2). The frequency of shoot induction and mean number of shoots varied with explant types (Table 2). Shoots were developed from the root explants in an interesting way: firstly, roots (in some parts) started to swell, then they produced compact callus 
that formed small balls arranged regularly on the root (Figure 2(A1)-2(A2)). As the culture time was extended, one clump of adventitious shoots eventually developed from one callus clump (Figure 2(A4)) and the results were monitored (Figure 2(A1)-2(A4)). Analysis of the data showed that significant differences in shoot induction and mean shoot numbers among the different treatments. For three types of explants, the combination of IAA and TDZ caused a significant increase in shoot induction and shoot formation relative to that induced by combinations of IAA and ZT or KIN. A maximum frequency of shoot induction was obtained on MS medium containing $3.0 \mathrm{mg} / \mathrm{L} \mathrm{TDZ}$, while a higher TDZ concentration $(4.0 \mathrm{mg} / \mathrm{L})$ decreased both the frequency of shoot induction and the mean number of shoots per explants. The treatment that yielded the greatest number of shoots was $0.4 \mathrm{mg} / \mathrm{L} \mathrm{IAA}$ and $3.0 \mathrm{mg} / \mathrm{L}$ TDZ, with $38.77 \pm 6.87$ shoots per root explant on average.

Leaf explants also showed a good response to in vitro culture. Organogenesis from leaf explants was induced indirectly via an intervening callus phase. The leaf explants initially enlarged on the inductive medium within the first 7 days of culture. They subsequently became swollen and curled and continued to develop for 5 days, pea-green compact callus appeared on the cut edges of the leaf explant. Thereafter, regenerated shoots arose from the callus originating in the cut margins after 2 weeks in culture (Figure 2(B2)-2(B3)) and its development was recorded (Figure 2(B1)-2(B4)). Significant differences in the rates of callus formation and organogenesis were observed in leaf explants (Table 2), with the highest rates obtained with $0.4 \mathrm{mg} / \mathrm{L}$ IAA and $3.0 \mathrm{mg} / \mathrm{L} \mathrm{TDZ}$, which yielded $42.73 \pm 7.75$ shoots per explant. The poorest organogenic treatments were $0.4 \mathrm{mg} / \mathrm{L}$ and IAA $1.0 \mathrm{mg} / \mathrm{L} \mathrm{Kin}$, as only a few shoots were produced (although more than the control lacking PGR ) (Table 2).

Shoots were developed from the nodal segment explants in two different ways: Indirect organogenesis (from the basal knot of the nodal segment) and direct organogenesis (from axillary bud shoot clumps). Indirect organogenesis was the main mode of induction observed, with an optimum combination of $3.0 \mathrm{mg} / \mathrm{L}$ TDZ plus 0.2 $\mathrm{mg} / \mathrm{L}$ IAA, which produced an average number of shoots per explants of $56.73 \pm 7.98$, with a $100 \%$ induction rate (Figure 2(C3)). An average of 19.58 \pm 3.56 shoots produced per nodal segment explant was observed with direct organogenesis, but with a low induction rate of $26.8 \%$ (Figure 2(C4)); data not shown). These data suggested that TDZ, a cytokinin, had a greater effect on shoot regeneration in $S$. nigrum than ZT with this method. MS medium with $0.5 \mathrm{mg} / \mathrm{L}$ IAA plus $1.0 \mathrm{mg} / \mathrm{L}$ TDZ was optimal for shoot proliferation as we can obtain a large scale regenerated shoots (Figure 3(A)-3(D)).

\section{ROOT DEVELOPMENT AND TRANSPLANTATION OF PLANTLETS}

Regenerated shoots larger than $4.0 \mathrm{~cm}$ in length were separated and transferred to rooting media. The presence of auxin was required for rooting. Media free of PGRs enabled root development, however, relatively few and small roots were developed under these conditions (Table 3 , rooting induction rate was $24.9 \%$, mean root number was 5.2 and root length was $3.4 \mathrm{~mm}$ ). In contrast, all applied NAA treatments in the present study induced rooting (Table 3 ). The best medium for rooting contained $0.5 \mathrm{mg} / \mathrm{L} \mathrm{NAA}$, in which $100 \%$ of the regenerated shoots developed roots after culturing for 30 days (Figure 3 ). The mean number of roots per regenerated plant was 24.73 , with an average root length of $10.1 \mathrm{~mm}$. A further increase in NAA concentration above $1.0 \mathrm{mg} / \mathrm{L}$ resulted in slow root development and the number of roots per plant decreased to 4.3 (Table 3 ). After 4 weeks of culture, well-developed plantlets were transferred to plastic pots containing peat and vermiculite $(3: 1 \mathrm{v} / \mathrm{v})$ with a $100 \%$ survival rate (data not shown).

\section{DISCUSSION}

The use of in vitro culture and biotechnological tools are critical for the conservation of the germplasm to ensure

TABLE 2. Effect of PGRs on shoot regeneration of S. nigrum after 4 weeks of culture

\begin{tabular}{|c|c|c|c|c|c|c|c|c|c|}
\hline \multicolumn{4}{|c|}{ PGRs (mg/L) } & \multicolumn{3}{|c|}{ Shoot induction (\%) } & \multicolumn{3}{|c|}{ Mean shoot number } \\
\hline IAA & KT & ZT & TDZ & Root & Leaf & $\begin{array}{l}\text { Nodal } \\
\text { segment }\end{array}$ & Root & Leaf & $\begin{array}{l}\text { Nodal } \\
\text { segment }\end{array}$ \\
\hline 0 & 0 & 0 & 0 & $0 \mathrm{e}$ & $0 \mathrm{~d}$ & $0 \mathrm{e}$ & $\mathrm{Od}$ & $0 \mathrm{e}$ & Of \\
\hline 0.4 & 1.0 & 0 & 0 & $65.3 \mathrm{~d}$ & $45.1 \mathrm{~d}$ & $54.3 \mathrm{~d}$ & $4.26 \pm 0.79 c$ & $1.52 \pm 0.76 \mathrm{~d}$ & $3.23 \pm 0.36 \mathrm{e}$ \\
\hline 0.4 & 3.0 & 0 & 0 & $72.3 \mathrm{~cd}$ & $79.2 \mathrm{bc}$ & $81.3 \mathrm{c}$ & $7.91 \pm 2.31 \mathrm{c}$ & $5.44 \pm 1.58 \mathrm{c}$ & $5.92 \pm 0.93 \mathrm{e}$ \\
\hline 0.4 & 4.0 & 0 & 0 & $69.2 \mathrm{~d}$ & $73.4 \mathrm{bc}$ & $77.4 \mathrm{c}$ & $7.72 \pm 3.42 \mathrm{c}$ & $3.74 \pm 0.11 \mathrm{~cd}$ & $3.46 \pm 1.15 \mathrm{e}$ \\
\hline 0.4 & & 1.0 & & $71.8 \mathrm{~cd}$ & $81.5 b$ & $83.2 \mathrm{c}$ & $12.23 \pm 3.74 b c$ & $17.2 \pm 5.89 \mathrm{~b}$ & $18.35 \pm 3.23 \mathrm{~d}$ \\
\hline 0.4 & & 3.0 & & $80.5 \mathrm{c}$ & $90.9 \mathrm{ab}$ & $93.1 \mathrm{ab}$ & $20.21 \pm 5.68 b$ & $20.1 \pm 6.54 b$ & $23.44 \pm 4.89 \mathrm{c}$ \\
\hline 0.4 & & 4.0 & & $67.8 \mathrm{~d}$ & $87.4 b$ & $89.8 \mathrm{bc}$ & $22.73 \pm 6.59 b$ & $19.84 \pm 6.77 b$ & $19.86 \pm 5.93 \mathrm{~d}$ \\
\hline 0.4 & & & 1.0 & $87.9 \mathrm{~b}$ & $91.2 \mathrm{ab}$ & $93.2 \mathrm{ab}$ & $30.22 \pm 4.74 \mathrm{a}$ & $22.33 \pm 5.46 b$ & $27.38 \pm 4.89 \mathrm{c}$ \\
\hline 0.4 & & & 3.0 & $100.0 \mathrm{a}$ & $100.0 \mathrm{a}$ & $100.0 \mathrm{a}$ & $38.77 \pm 6.87 \mathrm{a}$ & $42.73 \pm 7.75 \mathrm{a}$ & $56.73 \pm 7.98 \mathrm{a}$ \\
\hline 0.4 & & & 4.0 & $90.2 b$ & $94.5 \mathrm{a}$ & $96.5 \mathrm{a}$ & $34.50 \pm 2.32 \mathrm{a}$ & $39.26 \pm 8.16 \mathrm{a}$ & $45.74 \pm 5.81 \mathrm{~b}$ \\
\hline
\end{tabular}

Means followed by different letter in a column are statistically significant at $p<0.05$ 


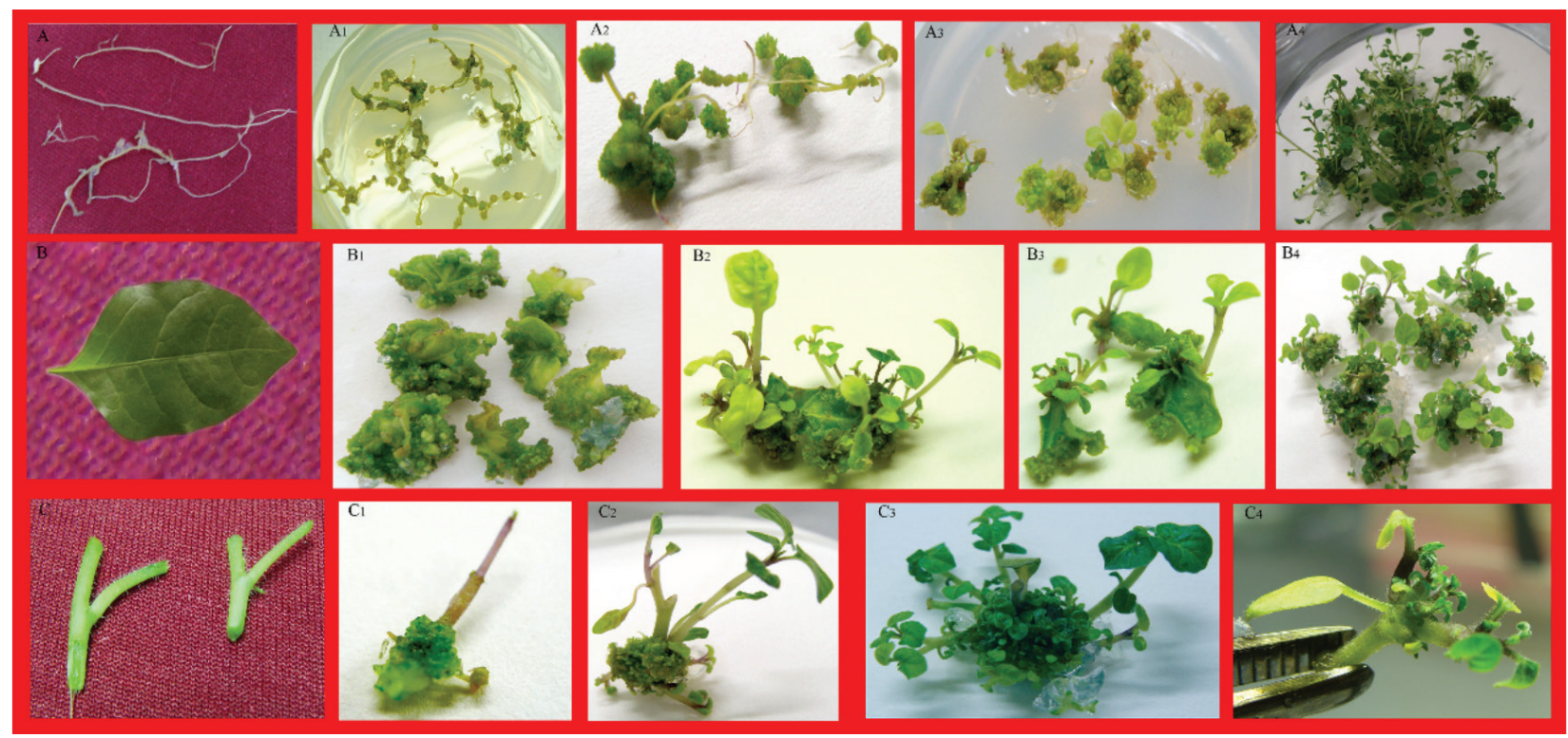

FIGURE 2. Callus development and organogenesis from root, leaf and nodal segment explants of S. nigrum on MS media with $0.2 \mathrm{mg} / \mathrm{L}$ IAA and $3.0 \mathrm{mg} / \mathrm{L}$ TDZ. A, B and C show representative root, leaf and nodal segment explants, respectively; A1-A3, B1 and C1-C2 show representative calli induced from root, leaf and nodal segment explants, respectively; A4, B4 and C3 show representative shoot organogenesis from root, leaf and nodal segment explants, respectively; C4 show representative direct organogenesis by nodal segment explants
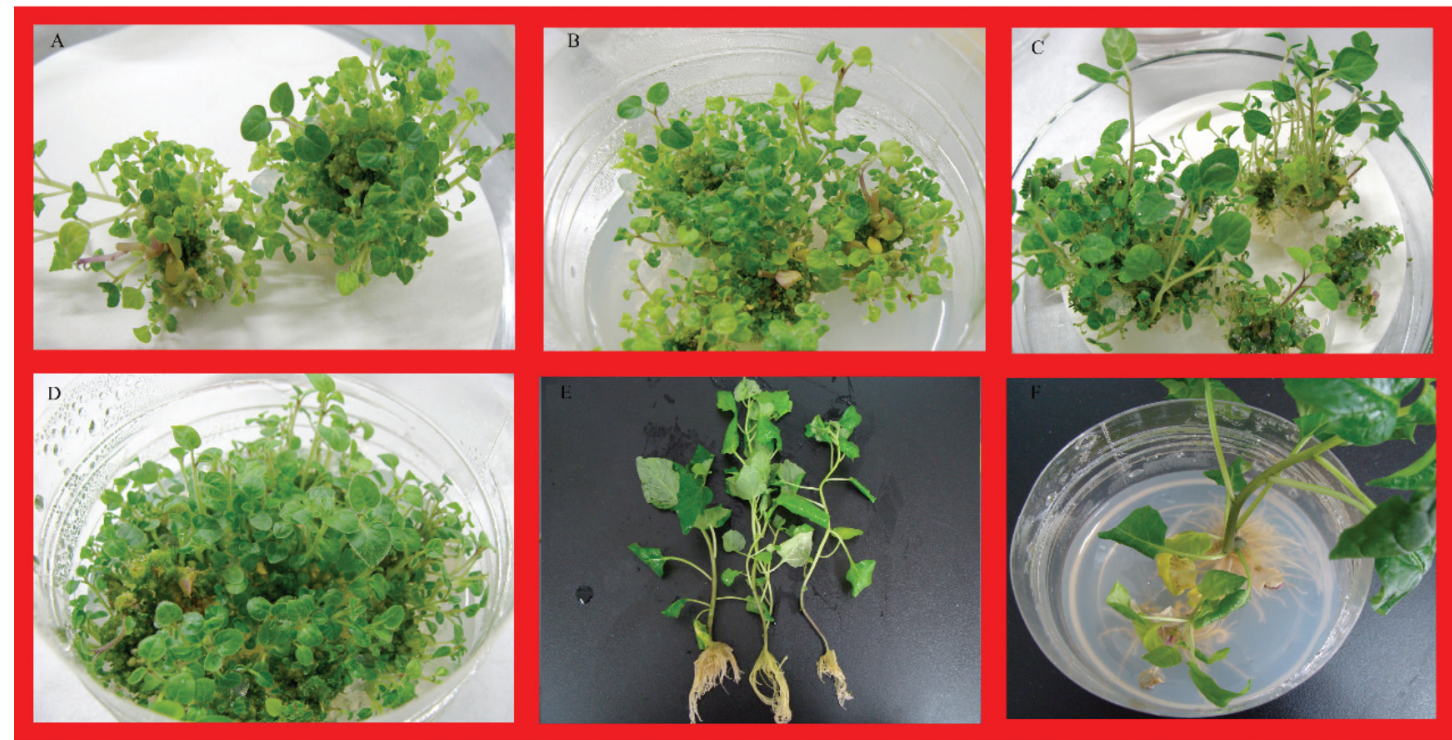

FIGURE 3. Multiplication culture of shoots of $S$. nigrum on MS media with $0.5 \mathrm{mg} / \mathrm{L}$ NAA and $1.0 \mathrm{mg} / \mathrm{L}$ TDZ after 20 days. A-D, shoot multiplication; E and F, rooting

propagation of valuable provenance material (Mallón et al. 2008). Previous studies showed that the exceptionally high regeneration potential of $S$. nigrum, both through somatic embryogenesis (Xu et al. 2014) and organogenesis (Xu et al. 2009). However, data on possible high-frequency regeneration and direct organogenesis from the five explants of $S$. nigrum are scarce. For some of the endangered or high medicinal value species, the clonal propagation is essential (Filipović et al. 2015). Shoots, leaves, nodal segments and less frequently, roots are used as explants to promote organogenesis phenomena (Mallón et al. 2011; Pourebad et al. 2015). In our assay, shoot regeneration was successfully induced from the above five types of explants of $S$. nigrum at a high frequency. Significant differences existed in mean shoot numbers among the five explants types (nodal $>$ rooted hypocotyls $>$ leaf $>$ root $>$ petiole) and similar observations were also made by $\mathrm{Xu}$ et al. (2014). In particular, leaves from in vitro grown plants are not only an easily available source of explants but also, very conveniently, plant regeneration via leaves to reduce the 
TABLE 3. Root formation in S. nigrum on different rooting medium

\begin{tabular}{cccc}
\hline $\begin{array}{c}\text { NAA } \\
(\mathrm{mg} / \mathrm{L})\end{array}$ & $\begin{array}{c}\text { Root induction } \\
\text { rate }(\%)\end{array}$ & $\begin{array}{c}\text { Mean root } \\
\text { number }\end{array}$ & $\begin{array}{c}\text { Mean root length } \\
(\mathrm{mm})\end{array}$ \\
\hline 0 & $24.9 \mathrm{~d}$ & $4.20 \pm 0.98 \mathrm{c}$ & $2.8 \pm 0.47 \mathrm{c}$ \\
0.5 & $83.3 \mathrm{~b}$ & $14.67 \pm 1.92 \mathrm{~b}$ & $5.2 \pm 0.72 \mathrm{~b}$ \\
1.0 & $96.7 \mathrm{a}$ & $24.73 \pm 3.86 \mathrm{a}$ & $10.1 \pm 1.23 \mathrm{a}$ \\
2.0 & $42.4 \mathrm{c}$ & $4.82 \pm 0.62 \mathrm{c}$ & $3.2 \pm 0.50 \mathrm{c}$ \\
\hline
\end{tabular}

Means followed by different letter in a column are statistically significant at $p<0.05$

possibility of genetic variation (Singh et al. 2013). In addition, shoot regeneration from nodal segments by direct organogenesis in vitro has not yet been reported for S. nigrum.

The cytokinins Kin and ZT (alone or in combination with auxins) are commonly used to induced callus formation and organogenesis in plant tissues (Kou et al. 2012; Sujatha \& Kumar 2007). In this study, all the cytokinins tested (KIN or ZT) could induced callus from petioles and rooted hypocotyls (Table 1). When these were combined with IAA in callus- induction media, they increased the callus induction percentage and mean shoots numbers, indicating that auxin (IAA) was a key factor in induced callus formation and organogenesis from the above two explants. Cytokinins (KIN, ZT or TDZ) were effective at inducing callus formation in $S$. nigrum explants (root, leaf and nodal segment), but the combination of TDZ with IAA generated higher frequencies of callus and increased mean shoots compared ZT or Kin. TDZ was reported to induce callus formation in a variety of plant culture systems with a higher rate than other growth regulators (Capelle et al. 1983; Murthy et al. 1998), which is also in agreement with the present study. Generally, a high cytoKinin-to-auxin ratio usually results in shoot induction (Krikorian 1995), but a higher ratio causes abnormal growth (Singh et al. 2013), which is in congruence with the present study - TDZ concentration increased to $3.0 \mathrm{mg} / \mathrm{L}$ gave a better response, but a higher concentrations $(4.0 \mathrm{mg} / \mathrm{L})$ was toxic to the explants and caused hyperhydricity. A recent study also showed that TDZ exhibits the unique property of mimicking both auxin and cytokinin effects on the growth and differentiation of cultured explants, although structurally it is different from either auxins or purine-based cytokinins (Singh et al. 2013). Xu et al. (2014) also reported that $20 \mathrm{mg} / \mathrm{L} \mathrm{TDZ}$ alone with resulted in a significantly higher frequency of FELB (frog egg-like bodies). However, our results indicated that a lower concentration TDZ $(3.0 \mathrm{mg} / \mathrm{L})$ in combination with $0.4 \mathrm{mg} / \mathrm{L}$ of IAA could lead to a higher frequency of organogenesis of three explants (root, leaf and nodal segment) of $S$. nigrum. Thus, these results may be explained by explant physiology and endogenous levels of regulators - a lower concentration of TDZ contributes to organogenesis but a higher concentration TDZ is conducive to the formation of FELB.
In conclusion, an efficient protocol was devised for organogenesis from five types of S. nigrum explants. The induction of multiple axillary shoots, complete with a high-frequency of propagation was achieved with this cost-effective regeneration protocol. This is a simple, economical, rapid and highly reproducible method to obtain more plantlets within a short time period. These plant regeneration systems were found to be reliable protocols and may be used in the future for genetic transformation and mass clonal propagation.

\section{CONCLUSION}

From these results it can be concluded that shoot organogenesis was induced in five explants. The highest mean number of shoots per petioles $(31.54 \pm 5.76)$ and rooted hypocotyls $(44.00 \pm 1.51)$ with a $100 \%$ induction rate were obtained on MS medium fortified with 0.4 $\mathrm{mg} / \mathrm{L} \mathrm{IAA}$ and $3.0 \mathrm{mg} / \mathrm{L} \mathrm{ZT}$. For roots, leaves and nodal segments, medium of $0.4 \mathrm{mg} / \mathrm{L}$ IAA and $3.0 \mathrm{mg} / \mathrm{L} \mathrm{TDZ}$ was found to be optimal for shoot regeneration. The highest regeneration frequency $(100 \%)$ with mean numbers of shoots $38.77 \pm 6.87$ for roots, $42.73 \pm 7.75$ for leaves and $56.73 \pm 7.98$ for nodal segments were produced.

\section{ACKNOWLEDGMENTS}

The research is supported by the National Natural Science Foundation of China (31100246), the key project from the Education Department of Sichuan Province (16ZA0322, 13TD0015, 13ZB0120 and 13ZB0121), the project of Mianyang Normal University (QD2015B07 and 2015A01) and the open project from the Ecological Security and Protection Key Laboratory of Sichuan Province (ESP1602).

\section{REFERENCES}

Acharya, E. \& Pokhrel, B. 2006. Ethno-medicinal plants used by Bantar of Bhaudaha, Morang, Nepal. Our Nature 4: 96-103.

Ben, A.S., Aung, B., Amyot, L., Lalin, I., Lachâal, M., KarrayBouraoui, N. \& Hannoufa, A. 2016. Salt stress $(\mathrm{NaCl})$ affects plant growth and branch pathways of carotenoid and flavonoid biosyntheses in Solanum nigrum. Acta Physiologiae Plantarum 38: 72.

Capelle, S.C., Mok, D.W., Kirchner, S.C. \& Mok, M.C. 1983. Effects of thidiazuron on cytokinin autonomy and the metabolism of $\mathrm{N}$-(delta-isopentenyl)[8-C] adenosine in callus tissues of Phaseolus lunatus L. Plant Physiol. 73: 796-802. 
Ewais, E.A., Desouky, S.A. \& Eshazly, E.H. 2015. Studies on callus induction, phytochemical constituents and antimicrobial activity of Solanum nigrum L. (Solanaceae). Nature and Science 3: 133-138.

Filipović, B.K., Simonović, A.D., Trifunović, M.M., Dmitrović, S.S., Savić, J.M., Jevremović, S.B. \& Subotić, A.R. 2015. Plant regeneration in leaf culture of Centaurium erythraea Rafn. Part 1: The role of antioxidant enzymes. Plant Cell Tissue Organ Cult. 121: 703-719.

Gomez, K.A. \& Gomez, A.A. 1984. Statistical Procedures for Agricultural Research. New York: Wiley.

Jain, R., Sharma, S., Gupta, S., Sarethy, I.P. \& Gabrani, R. 2011. Solanum nigrum: Current perspectives on therapeutic properties. Altern. Med. Rev. 16: 78-85.

Jawad, B.O., Samaraie, K.W. \& Alfaisl, A.M. 2015. Effects of Solanum nigrum aqueous extract on normal and cancer cells line. IOSR J. Pharm. Biol. Sci. 10: 34-38.

Jiang, Q.Y., Tan, S.Y., Zhuo, F., Yang, D.J., Ye, Z.H. \& Jing, Y.X. 2016. Effect of funneliformis mosseae on the growth, cadmium accumulation and antioxidant activities of Solanum nigrum. Appl. Soil Ecol. 98: 112-120.

Khan, A.R., Ullah, I., Khan, A.L., Hong, S.J., Waqas, M. \& Park, G.S. 2014. Phytostabilization and physicochemical responses of Korean ecotype Solanum nigrum L. to cadmium contamination. Water Air Soil Poll. 225: 1-11.

Khan, A.R., Ullah, I., Waqas, M., Shahzad, R., Hong, S.J., Park, G.S., Jung, B.K., Lee, I.J. \& Shin, J.H. 2015. Plant growthpromoting potential of endophytic fungi isolated from Solanum nigrum leaves. World J. Microbiol. Biotechnol. 3: 1461-1466.

Kou, Y., Ma, G., Teixeira, J.A. \& Liu, N. 2012. Callus induction and shoot organogenesis from anther cultures of Curcuma attenuata Wall. Plant Cell Tissue Organ Cult. 112: 1-7.

Krikorian, A.D. 1995. Hormones in tissue culture and micropropagation. In Plant Hormones: Physiology, Biochemistry and Molecular Biology, edited by Davies, P.J., Dordrecht: Kluwer. pp. 774-796.

Lin, H.M., Tseng, H.C., Wang, C.J., Lin, J.J., Lo, C.W. \& Chou, F.P. 2008. Hepatoprotective effects of Solanum nigrum L. extract against CCI 4- induced oxidative damage in rats. Chem. Biol. Interact. 171: 283-93.

Mallón, R., Bunn, E., Turner, S.R. \& Gonza'lez, M.L. 2008. Cryopreservation of Centaurea ultreiae (Compositae) a critically endangered species from Galicia (Spain). Cryo. Letters 29: 363-370.

Mallón, R., Rodríguez-Oubiña, J. \& González, M.L. 2011. Shoot regeneration from in vitro-derived leaf and root explants of Centaurea ultreiae. Plant Cell Tissue Organ Cult. 106: 523-530.

Murashige, T. \& Skoog, F. 1962. A revised medium for rapid growth and bioassays with tabocco tissue cultures. Physiol. Plantarum 15: 473-479.

Murthy, B.N.S., Murch, S.J. \& Saxena, P.K. 1998. Thidiazuron: A potent regulator of in vitro plant morphogenesis. In Vitro Cell Dev. Plant 34: 267-275.

Pourebad, N., Motafakkerazad, R., Kosari-Nasab, M., Farsad Akhtar, N. \& Movafeghi, A. 2015. The influence of TDZ concentrations on in vitro growth and production of secondary metabolites by the shoot and callus culture of Lallemantia iberica. Plant Cell Tissue Organ Cult. 122: 331-339.
Sarethy, I.P., Kashyap, A., Bahal, U., Sejwal, N. \& Gabrani, R 2014. Study of liquid culture system for micropropagation of the medicinal plant Solanum nigrum L. and its effect on antioxidant property. Acta Physiol. Plant 36: 2863-2870.

Singh, C.K., Raj, S.R., Patil, V.R., Jaiswal, P.S. \& Subhash, N. 2013. Plant regeneration from leaf explants of mature sandalwood (Santalum album L.) trees in vitro conditions. In Vitro Cell Dev. Plant 49: 216-222.

Soares, C., Sousa, A., Pinto, A., Azenha, M., Teixeira, J.,Azevedo, R.A.\& Fidalgo, F. 2016. Effect of 24-epibrassinolide on ROS content, antioxidant system, lipid peroxidation and $\mathrm{Ni}$ uptake in Solanum nigrum L. under Ni stress. Environ. Exp. Bot. 122: $115-125$.

Sujatha, M. \& Kumar, D. 2007. In vitro bud regeneration of Carthamus tinctorius and wild Carthamus species from leaf explants and axillary buds. Biol. Plantarum 51: 782-786.

Tai, C.J., Wang, C.K., Tai, C.J., Lin, Y.F., Lin, C.S., Jian, J.Y., Chang, Y.J. \& Chang, C.C. 2013. Aqueous extract of Solanum nigrum leaves induces autophagy and enhances cytotoxicity of cisplatin, doxorubicin, docetaxel, and 5-fluorouracil in human colorectal carcinoma cells. Evid-Based Compl. Alt. 2013: 514719.

UdDin, I., Bano, A. \& Masood, S. 2015. Chromium toxicity tolerance of Solanum nigrum L. and Parthenium hysterophorus L. plants with reference to ion pattern, antioxidation activity and root exudation. Ecotox. Environ. Safe. 113: 271-278.

Wang, H.C., Chung, P.J., Wu, C.H., Lan, K.P., Yang, M.Y. \& Wang, C.J. 2011. Solanum nigrum L. polyphenolic extract inhibits hepatocarcinoma cell growth by inducing $\mathrm{G} 2 / \mathrm{M}$ phase arrest and apoptosis. J. Sci. Food Agricult. 91: 178-185.

Xu, J., Yin, H. \& Li, X. 2009. Protective effects of proline against cadmium toxicity in micropropagated hyperaccumulator, Solanum nigrum L. Plant Cell Rep. 28: 325-333.

Xu, K., Chang, Y.X., Liu, K., Wang, F.G., Liu, Z.Y., Zhang, T., Li, T. \& Yi, Z. 2014. Regeneration of Solanum nigrum by somatic embryogenesis, involving frog egg-like body, a novel structure. Plos One 9: e98672.

Zakaria, Z.A., Zainal, H.H., Mogd-pojan, N.H., Morsid, N.A., Aris, A. \& Sulaiman, M.R. 2006. Antinociceptive, antiinflammatory and antipyretic effects of Solanum nigrum chloroform extract in animal models. Yakugaku Zasshi 126 : 1171-1178.

Ecological Security and Protection Key Laboratory of Sichuan Province

Mianyang Normal University

621000 Mianyang

China

*Corresponding author; email: qgwu30@163.com

Received: 24 May 2016

Accepted: 25 January 2017 